\title{
Household Headship and Women's Health: An Exploratory Study from Egypt
}

\author{
Mona I. El-Lawindi, Hend Aly Sabry, Eman Hany Elsebaie
}

Department of Public Health and Community Medicine, Faculty of Medicine, Cairo University, Egypt

Received: July, 2018 Accepted: October, 2018

\section{Abstract:}

Background: Despite of the efforts done to achieve women's empowerment as one of the 17 Sustainable Development Goals, women still suffer from unequal access to education besides several illnesses contributing to chronic diseases development. Women Headed Families (WHF) are a major concern nowadays as it can be considered as a risk factor for many morbidities and social problems. Therefore, this study was conducted to draw attention to the uprising vulnerability trend of WHF. Objectives: to compare the socio-demographic characteristics and pattern of morbidities between females heading families and those who do not. Method: A cross-sectional study was conducted at Met-Rahena Village in Egypt. A purposive sample of 886 females were interviewed. The questionnaire included questions about education, work status, and several morbidities. Data was analyzed using SPSS 20.0. The Chi-square or Fisher Exact tests were used to analyze the association between variables. Results: The mean age of the females heading a family was (47.3) years, which was significantly higher than the mean age of females not heading a family (36.1) years. The studied types of morbidities appeared to be represented higher in the group of females heading a family than in the other group, namely; hypertension, diabetes mellitus, GIT diseases, ophthalmological problems and musculoskeletal disorders $(p<0.05)$. Conclusion and Recommendation: As the health status of women heading families is not desirable, so there is a great need for effective interventions directed to this vulnerable group to improve their quality of life.

Keywords: women's health, female household headship, morbidities.

Corresponding author: Eman Hany Ahmed Elsebaie. Email: eman.hs@ hotmail.com, Tel: 01005645129

\section{Introduction:}

While the world has achieved progress towards gender equality and women's empowerment under the Millennium Development Goals (including equal access to primary education between girls and boys), women and girls continue to suffer discrimination and violence in every part of the world. Gender equality is not only a fundamental human right, but a necessary foundation for a peaceful, prosperous and sustainable world.
Providing women and girls with equal access to education, health care, decent work, and representation in political and economic decision-making processes will fuel sustainable economies and benefit societies and humanity at large. ${ }^{1}$ The European Union (EU) and the United Nations (UN) are embarking on a new, global, multi-year initiative focused on eliminating all forms of violence against women and girls. Women's equality and 
empowerment is one of the 17 Sustainable Development Goals, but also integral to all dimensions of inclusive and sustainable development. Gender equality by 2030 requires urgent action to eliminate the many root causes of discrimination that still curtail women's rights in private and public spheres. ${ }^{1}$ For example, women do 2.6 times more unpaid care and domestic work than men. While families, societies and economies depend on this work, for women, it leads lower earnings and less time to engage in non-work activities. In addition to equal distribution of economic resources, which is not only a right, but accelerates development in multiple areas, there needs to be a fair balance of responsibility for unpaid care work between men and women. ${ }^{1}$ The household is regarded as the fundamental social and/ or economic unit of society. ${ }^{4}$ In recent decades the new form of households emerged. House headed by women have become more significant phenomenon worldwide in the last half of 20th and 21th century. ${ }^{5}$ In 1960 only 9 percent of families with children in united-states were headed by none married women; by 1999 the number was over 20 percent. $^{6}$ A more recent occurrence in this direction is the increasing number of women headed households in developing countries that are emerging as a result of economic changes, economic downturns and social pressures, rather than as a product of cultural patterns. In many countries in the third world, like Asian or Latin American countries, in recent years, there has been a significant increase in the percentage of female-headed households (FHH). ${ }^{4}$ Problems facing women- headed families are: poverty, economic insecurity, social, political, powerlessness, and health problems. While problems facing their children are: poverty, social, and health problems. Data from nearly 50 national demographic and health surveys show that on average a woman is head of one in five households and that these households are particularly vulnerable to poverty. ${ }^{7}$ In Iraq, one in 10 Iraqi households is headed by woman according to International Organization for Migration (IOM), though their assessments suggest that this ratio increases to 1 in 8 once the families have been displaced. In 2010 the percentage of women headed families (WHF) is $7.7 \%$ as a whole, $8.9 \%$ in urban and $4.5 \%$ in rural areas. $^{7}$ A woman's health is her total wellbeing, not determined solely by biological factors and reproduction, but also by effects of work load, nutrition, stress, war and migration, among others. ${ }^{2}$ Women's health is an important topic that has been neglected in the past. Many of the studies done on disease and its prevention were focused on men. ${ }^{3}$ Today, however, women's health is taking on a higher position in society and people are realizing that while women have many of the same diseases as men, their symptoms and treatments may not always be the same. ${ }^{2}$ Women's health issues deserve as much attention as men since health care matters impact women differently than men. Plus, Women do represent fifty one percent of the population. ${ }^{3}$ Women often suffer from diseases specific to their gender but they also are stricken with diseases previously thought to only affect men. ${ }^{3}$ The fact that many women juggle both work and the care of the home only increases their susceptibility to poor health if care is not taken. $^{3}$ A number of illnesses that affect women's health can be genetic in nature but others occur due to the effects of poor habits such as smoking, drugs and alcohol, and obesity. ${ }^{3}$ Based on the above mentioned facts this study was conducted to draw attention to the uprising vulnerability trend of WHF and their important medical and social problems. 
The study will explore the patterns of morbidities and their possible predictors among WHF.

The aim of the study is To compare the socio-demographic characteristics between females heading families and those not heading families, to determine the occurrence of morbidities among females heading families and those do not, to describe the pattern of morbidities among females heading families and those do not.

\section{Method}

Study design, Sampling \& tool: The study is a cross sectional survey conducted at Met-Rahina" village, Badrashin, Giza, Egypt. The village was divided into geographical clusters. The household units within each cluster were identified and included within a sequential approach. A total of 886 household unit were included.

Sampling technique: A purposive sampling technique was used to recruit participants' female village residents who accepted to participate in the study. A total of 886 females were interviewed by the researchers during the study period starting October 2016 through June 2017. Study tools: Data were collected at every family's house after informed consent has been obtained. The anonymous questionnaire used for data collection was the same tool used in (PHCM, 2016) ${ }^{(8)}$. The tool contained items questioning for: education and work status, whether the participant woman is heading a family or not, smoking, addiction, and several morbidities which the participant may have been suffering from.

Ethical Consideration: Local research ethical committee approval was issued before starting data collection and an oral informed consent was taken from each participant. The study protocol conformed to the ethical guidelines of the 2008 Declaration of Helsinki.
Data management \& statistical analysis: Collected data was cleaned and entered into a Microsoft Excel (version 2010) database and analyzed using SPSS version 20.0. Descriptive statistics was used to compute means, median, standard deviations and interquartile range for numerical variables as well as frequencies for nominal variables. Initially, the data was assessed for normality and this was followed by an exploratory univariate inferential analysis for the studied to assess differences between groups using student's t-test, chi-square, Mann-Whitney \& Fisher Exact tests as indicated. To assess the possible associated risk between studied variables, the odds ratio was calculated. The results were considered statistically significant for a value of $\mathrm{p}<0.05$.

\section{Results:}

The study sample included (886) female participants, (58) of them were heading a family and (828) were not, with a percent of $7 \%$ of the sampled women headed a family (Figure 1). The mean age of the females heading a family was (47.3) years S.D (11.2), which was significantly higher than the mean age of females not heading a family (36.1) years S.D (12). The educational status didn't differ significantly between both groups with about half the sampled women were

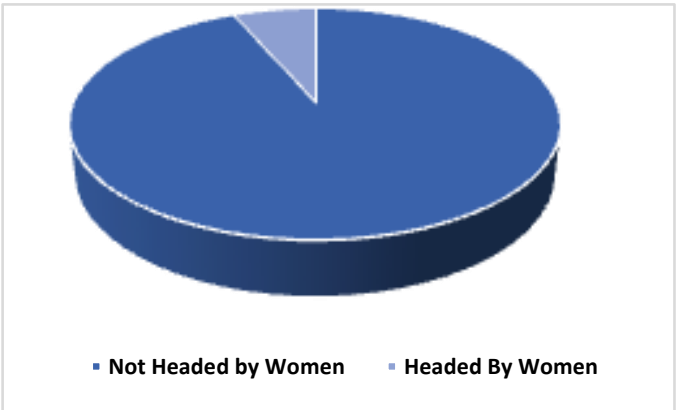

Figure 1. Percent of female participants heading a family in relation to the whole sample. 
educated. Among the females heading a family, $(80.6 \%)$ of them were inhabiting houses of crowding index of 2 or less members / room, in contrast to $(62.6 \%)$ of the females not heading a family were inhabiting houses with crowding index of 2 or less members / room, with a $p$ value of (0.03). Females heading a family appeared to be significantly more smokers than those who are not heading a family $(\mathrm{p}=0.01)$ and an odds ratio of 6.1 , while the situation wasn't significantly different in case of addiction (Table 1). The studied types of morbidities appeared to be represented higher in the group of females heading a family than in the other group (Figure 2). Namely; hypertension with an odds ratio of (2.7), diabetes mellitus with an odds ratio of (2.3), GIT diseases with an odds ratio of (2.6), ophthalmological problems with an odds ratio od (2.3) and musculoskeletal disorders with an odd ratio of (4.8) were found to be significantly higher in the group of females heading a family than in the group of females not heading a family. Musculoskeletal disorders recorded the higher odds ratio. The rest of diseases didn't show significant difference between the two groups. It's worth mentioning that in the sampled women heading a family, none of them

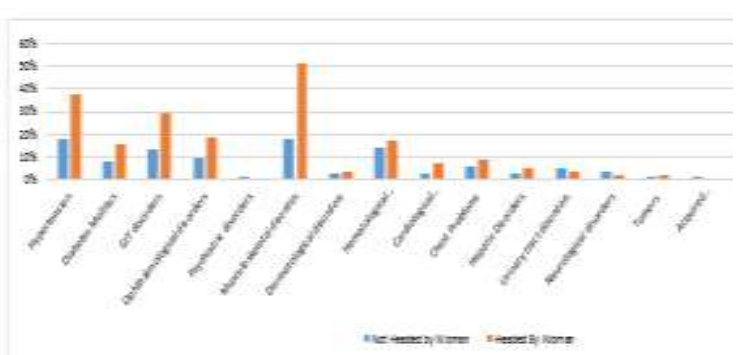

Figure 2. Percent distribution of morbidities among female participants.

Percents may sum up to more than $100 \%$ due to comorbidities

reported having psychiatric problems. Also the presence of more than 2 morbidities showed to be significantly higher among the group of females heading a family with an odds ratio of approximately three that women heading a family are more prone to have more than 2 morbidities (Table 2). It was found that there was significant difference in age in both groups regarding whether the females had 2 or less comorbidities or more than 2 comorbidities; with increasing comorbidities as the mean age increases. A significant difference was also found in the group of females not heading a family regarding their educational status showing less comorbidities with better status of education (Table 3).

\section{Discussion:}

The increase in the proportion of female headed households is a global trend. ${ }^{9}$ Each day a reasonable number of women are widowed and the number of families struggling to cope without a wage-earner is starting to overwhelm local social services. ${ }^{10}$ In the current study, the mean age of females heading a family was (47.3) years SD (11.2) which was significantly higher than the mean age of females not heading a family (36.1) years SD (12). This goes in concordance with the study performed by Riyadh et al in $2012^{7}$ who found the rate of WHF increases with age, the peak rate $44 \%$ is at $40-49$. Furthermore, in the studies performed by Rimaz et al., Morasae et al., Akinsola et al., and Klasen et al., most of the participated women as heads of households were middle-aged with high school education. $^{11}$ However, this is different from what Khadim found in his study in 2006 in Baghdad ${ }^{12}$, where the highest rate was $27.7 \%$ and among the age group of 35-44 year. Furthermore, this study indicated that the educational status didn't differ significantly between both groups with about half the sampled women were 
Table (1): Distribution of female participants at Meet Rahina village in relation to their characteristics distributed by their status of heading a family:

\begin{tabular}{|c|c|c|c|c|c|}
\hline $\begin{array}{c}\text { Characteristics } \\
\text { items }\end{array}$ & $\begin{array}{c}\text { Heading a } \\
\text { family }(n=58)\end{array}$ & $\begin{array}{l}\text { Not heading a } \\
\text { family }(n=828)\end{array}$ & $\begin{array}{c}\text { Total: no. } \\
(\%)\end{array}$ & $\begin{array}{l}\text { Odds ratio } \\
\quad(95 \% \\
\text { confidence } \\
\text { intervals })\end{array}$ & P value \\
\hline $\begin{array}{l}\text { - Age: } \\
\text { Mean (SD) } \\
\text { Median (IQR) }\end{array}$ & $\begin{array}{c}47.3(11.2) \\
47.5(40-55)\end{array}$ & $\begin{array}{c}36.1(12) \\
34.0(27-44)\end{array}$ & & & $0.001 * *$ \\
\hline $\begin{array}{c}\text { - Education: } \\
\text { Yes } \\
\text { No }\end{array}$ & $\begin{array}{l}24(41.4) \\
34(58.6)\end{array}$ & $\begin{array}{l}442(53.4) \\
386(46.6)\end{array}$ & $\begin{array}{l}466(52.6) \\
420(47.4)\end{array}$ & $\begin{array}{c}1.62 \\
(0.95-2.8)\end{array}$ & $0.07 *$ \\
\hline $\begin{array}{l}\text { - Crowding index: } \\
\quad \leq 2 \\
>2 \\
\end{array}$ & $\begin{array}{r}29(80.6) \\
7(19.4) \\
\end{array}$ & $\begin{array}{l}67(62.6) \\
40(37.4)\end{array}$ & $\begin{array}{r}96(67.1) \\
47(32.9) \\
\end{array}$ & $\begin{array}{c}0.4 \\
(0.2-1)\end{array}$ & $0.03 *$ \\
\hline $\begin{array}{l}\text { Smoking } \\
\text { (cigarettes- } \\
\text { shisha): } \\
\text { Yes } \\
\text { No }\end{array}$ & $\begin{array}{r}4(6.9) \\
54(93.1)\end{array}$ & $\begin{array}{r}10(1.2) \\
818(98.8)\end{array}$ & $\begin{array}{r}14(1.6) \\
872(98.4)\end{array}$ & $\begin{array}{c}6.1 \\
(1.8-19.1)\end{array}$ & $0.01 *$ \\
\hline $\begin{array}{l}\text { - Addiction: } \\
\text { Yes } \\
\text { No }\end{array}$ & $\begin{array}{r}0(0) \\
58(100)\end{array}$ & $\begin{array}{r}2(0.2) \\
826(99.8)\end{array}$ & $\begin{array}{r}2(0.2) \\
884(99.8)\end{array}$ & & $0.8^{*}$ \\
\hline
\end{tabular}

SD: standard deviation, IQR=interquartile range, ${ }^{*}$ Chi-square, $* *$ Mann Whitney test.

Numbers may count to less than the total because of missed responses, valid percents were used.

educated and the crowding index appeared to be significantly preferable among the group of females heading a family more than the group not heading a family with a $\mathrm{p}$ value of 0.03 . This differs from Riyadh study ${ }^{7}$ who found low educational status of most of the households with poor nutritional status due to poverty. The current study found that females heading a family appeared to be significantly high smokers than those not heading a family with a $\mathrm{p}$ value of 0.01 and an odds ratio of 6.1. While the situation wasn't significantly different in case of addiction. This comes in agreement with Graham who stated also that there was a high prevalence of smoking and cigarette consumption. ${ }^{16}$ According to the results of this study, the majority of morbidities appeared to be higher in the group of females heading a family than in the other group, namely; hypertension with an odds ratio of (2.7), diabetes mellitus with an odds ratio of (2.3), GIT diseases with an odds ratio of (2.6), ophthalmological problems with an odds ratio od (2.3) and musculoskeletal disorders with an odd ratio of (4.8) were found to be significantly higher in the group of females heading a family than in the group of females not heading a family. The mother usually neglects her health for the sake of her household and; unless the disease becomes severe or intolerable she does not attend the health facilities or seeks health care in late stages. ${ }^{7}$ On the other hand, demanding health services may affect the household from the economic point of view; keep less money for the essential household requirements. ${ }^{7}$ This strongly agrees with Riyadh study who found hypertension is the leading disease (20\%) followed by arthritis $(9.6 \%)$, heart disease $(7.6 \%)$, and diabetes mellitus $(5.2 \%)$, the least was tuberculosis $(0.1 \%) .^{7}$ Moreover, in the present research, musculoskeletal disorders 
Table (2): Distribution of female participants at Meet Rahina village in relation to their morbidities distributed by their status of heading a family.

\begin{tabular}{|c|c|c|c|c|c|}
\hline Morbidity items & $\begin{array}{c}\text { Heading a } \\
\text { family }(n=58)\end{array}$ & $\begin{array}{l}\text { Not heading a } \\
\text { family }(n=828)\end{array}$ & $\begin{array}{c}\text { Total: no. } \\
(\%)\end{array}$ & $\begin{array}{l}\text { Odds ratio } \\
\quad(95 \% \\
\text { confidence } \\
\text { intervals }) \\
\end{array}$ & P value* \\
\hline $\begin{array}{l}\text { Hypertension: } \\
\text { Yes } \\
\text { No } \\
\end{array}$ & $\begin{array}{l}22(37.9) \\
36(62.1)\end{array}$ & $\begin{array}{l}149(18) \\
679(82)\end{array}$ & $\begin{array}{l}171(19.3) \\
715(80.7)\end{array}$ & $\begin{array}{c}2.7 \\
(1.5-4.8)\end{array}$ & 0.001 \\
\hline $\begin{array}{c}\text { Diabetes Mellitus: } \\
\text { Yes } \\
\text { No } \\
\end{array}$ & $\begin{array}{r}9(15.5) \\
49(84.5) \\
\end{array}$ & $\begin{array}{r}63(7.6) \\
765(92.4) \\
\end{array}$ & $\begin{array}{r}72(8.1) \\
814(91.9) \\
\end{array}$ & $\begin{array}{c}2.3 \\
(1-4.7)\end{array}$ & 0.03 \\
\hline $\begin{array}{l}\text { GIT problems: } \\
\text { Yes } \\
\text { No } \\
\end{array}$ & $\begin{array}{l}17(29.3) \\
41(70.7) \\
\end{array}$ & $\begin{array}{l}113(13.6) \\
715(86.4) \\
\end{array}$ & $\begin{array}{l}130(14.7) \\
756(85.3)\end{array}$ & $\begin{array}{c}2.6 \\
(1.4-4.8) \\
\end{array}$ & 0.001 \\
\hline $\begin{array}{l}\text { - Ophthalmological problems: } \\
\text { Yes } \\
\text { No } \\
\end{array}$ & $\begin{array}{l}11(19) \\
47(81)\end{array}$ & $\begin{array}{r}77(9.3) \\
751(90.7) \\
\end{array}$ & $\begin{array}{r}88(9.9) \\
798(90.1) \\
\end{array}$ & $\begin{array}{c}2.3 \\
(1.1-4.6)\end{array}$ & 0.01 \\
\hline $\begin{array}{l}\text { Psychiatric disorders: } \\
\text { Yes } \\
\text { No }\end{array}$ & $\begin{array}{r}0(0) \\
58(100)\end{array}$ & $\begin{array}{r}7(0.8) \\
821(99.2)\end{array}$ & $\begin{array}{r}7(0.8) \\
879(99.2)\end{array}$ & & 0.6 \\
\hline $\begin{array}{l}\text { - Musculoskeletal disorders: } \\
\text { Yes } \\
\text { No } \\
\end{array}$ & $\begin{array}{l}30(57.1) \\
28(48.3)\end{array}$ & $\begin{array}{l}150(18.1) \\
678(81.9)\end{array}$ & $\begin{array}{l}180(20.3) \\
706(79.7)\end{array}$ & $\begin{array}{c}4.8 \\
(2.8-8.3)\end{array}$ & 0.001 \\
\hline $\begin{array}{l}\text { - Dermatological Problems: } \\
\text { Yes } \\
\text { No } \\
\end{array}$ & $\begin{array}{r}2(3.4) \\
56(96.6) \\
\end{array}$ & $\begin{array}{r}24(2.9) \\
804(97.1) \\
\end{array}$ & $\begin{array}{r}26(2.9) \\
860(97.1) \\
\end{array}$ & $\begin{array}{c}1.2 \\
(0.3-3.6) \\
\end{array}$ & 0.5 \\
\hline $\begin{array}{l}\text { - Hematological Problems: } \\
\text { Yes } \\
\text { No } \\
\end{array}$ & $\begin{array}{l}10(17.2) \\
48(82.8) \\
\end{array}$ & $\begin{array}{l}114(13.8) \\
714(86.2) \\
\end{array}$ & $\begin{array}{l}124(14) \\
762(86) \\
\end{array}$ & $\begin{array}{c}1.3 \\
(0.6-2.7) \\
\end{array}$ & 0.4 \\
\hline $\begin{array}{l}\text { Cardiological Problems: } \\
\text { Yes } \\
\text { No } \\
\end{array}$ & $\begin{array}{r}4(6.9) \\
54(93.1) \\
\end{array}$ & $\begin{array}{r}21(2.5) \\
807(97.5) \\
\end{array}$ & $\begin{array}{r}25(2.8) \\
861(97.2) \\
\end{array}$ & $\begin{array}{c}2.8 \\
(0.9-8.6)\end{array}$ & 0.07 \\
\hline $\begin{array}{l}\text { Chest problems: } \\
\text { Yes } \\
\text { No } \\
\end{array}$ & $\begin{array}{r}5(8.6) \\
53(91.4) \\
\end{array}$ & $\begin{array}{r}44(5.3) \\
784(94.7) \\
\end{array}$ & $\begin{array}{r}49(5.5) \\
837(94.5) \\
\end{array}$ & $\begin{array}{c}1.6 \\
(0.6-4.4) \\
\end{array}$ & 0.2 \\
\hline $\begin{array}{l}\text { - Hepatic disorders: } \\
\text { Yes } \\
\text { No } \\
\end{array}$ & $\begin{array}{r}3(5.2) \\
55(94.8) \\
\end{array}$ & $\begin{array}{r}24(2.9) \\
804(97.1) \\
\end{array}$ & $\begin{array}{r}27(3) \\
859(97) \\
\end{array}$ & $\begin{array}{c}1.8 \\
(0.5-6.3) \\
\end{array}$ & 0.25 \\
\hline $\begin{array}{l}\text { - Urinary tract \& Kidney diseases: } \\
\text { Yes } \\
\text { No }\end{array}$ & $\begin{array}{r}2(3.4) \\
56(96.6)\end{array}$ & $\begin{array}{r}40(4.8) \\
788(95.2)\end{array}$ & $\begin{array}{r}42(4.7) \\
844(95.3)\end{array}$ & $\begin{array}{c}0.7 \\
(0.1-2.9)\end{array}$ & 0.4 \\
\hline $\begin{array}{lll}\text { - Cerebral } & \& & \text { neurological } \\
\text { diseases: } & & \\
\text { Yes } & & \\
\text { No } & & \\
\end{array}$ & $\begin{array}{r}1(1.7) \\
57(98.3)\end{array}$ & $\begin{array}{r}31(3.7) \\
797(96.3)\end{array}$ & $\begin{array}{r}32(3.6) \\
854(96.4)\end{array}$ & $\begin{array}{c}0.5 \\
(0.1-3.4)\end{array}$ & 0.36 \\
\hline $\begin{array}{l}\text { - Tumors: } \\
\text { Yes } \\
\text { No } \\
\end{array}$ & $\begin{array}{r}1(1.7) \\
57(98.3) \\
\end{array}$ & $\begin{array}{r}4(0.5) \\
824(99.5) \\
\end{array}$ & $\begin{array}{r}5(0.6) \\
881(99.4) \\
\end{array}$ & $\begin{array}{c}3.6 \\
(0.4-32.9) \\
\end{array}$ & 0.29 \\
\hline $\begin{array}{l}\text { Acquired disabilities (accidents): } \\
\text { Yes } \\
\text { No }\end{array}$ & $\begin{array}{r}0(0) \\
58(100)\end{array}$ & $\begin{array}{r}2(0.2) \\
826(99.8)\end{array}$ & $\begin{array}{r}2(0.2) \\
884(99.8)\end{array}$ & & 0.8 \\
\hline $\begin{array}{c}\text { Comorbidities: } \\
\leq 2 \\
>2\end{array}$ & $\begin{array}{l}40(69) \\
18(31)\end{array}$ & $\begin{array}{r}718(86.7) \\
110(3.3)\end{array}$ & $\begin{array}{l}128(14.4) \\
758(85.6)\end{array}$ & $\begin{array}{c}2.9 \\
(1.6-5.3)\end{array}$ & 0.001 \\
\hline
\end{tabular}

*Chi-square for independent samples

Numbers may count to less than the total because of missed responses, valid percents were used.

recorded the higher odds ratio. This also agrees with Riyadh study in which arthritis occurs at a high rate (9.6\%); this is probably attributed to the abuse of their joints in hard labor to cover the needs of their families. ${ }^{7}$ The rest of diseases didn't show significant difference between the two groups. According to this study, it's worth mentioning that in the sampled women heading a family, none of them 
Table (3): Distribution of female participants at Meet Rahina village in relation to their characteristics distributed by their status of comorbidities:

\begin{tabular}{|c|c|c|c|c|c|c|}
\hline \multirow[b]{3}{*}{ Characteristics } & \multicolumn{6}{|c|}{ Comorbidity } \\
\hline & \multicolumn{3}{|c|}{ Females heading a family: no. (\%) } & \multicolumn{3}{|c|}{ Females not heading a family: no. (\%) } \\
\hline & $\begin{array}{c}2 \text { or less } \\
\text { morbidities } \\
(n=40)\end{array}$ & $\begin{array}{c}\text { More than } 2 \\
\text { morbidities } \\
(n=18)\end{array}$ & P value & $\begin{array}{c}2 \text { or less } \\
\text { morbidities } \\
(n=718)\end{array}$ & $\begin{array}{c}\text { More than } 2 \\
\text { morbidities } \\
(n=110)\end{array}$ & P value \\
\hline $\begin{array}{l}\text { - Age: } \\
\text { Mean (SD) } \\
\text { Median (IQR) }\end{array}$ & $\begin{array}{r}44.4(9.4) \\
44(39.3-50)\end{array}$ & $\begin{array}{r}53.8(12.3) \\
55(47.8-62.8)\end{array}$ & $0.003 * *$ & $\begin{array}{r}34.8(11.5) \\
32.0(27-41.25)\end{array}$ & $\begin{array}{r}44.8(12) \\
45.0(34.7-55.2)\end{array}$ & $0.001 * *$ \\
\hline $\begin{array}{c}\text { - Education: } \\
\text { Yes } \\
\text { No }\end{array}$ & $\begin{array}{l}18(45) \\
22(55)\end{array}$ & $\begin{array}{r}6(33.3) \\
12(66.7)\end{array}$ & $0.41 *$ & $\begin{array}{l}394(54.9) \\
324(45.1)\end{array}$ & $\begin{array}{r}48(43.6) \\
62(56.4)\end{array}$ & $\mathbf{0 . 0 3 *}$ \\
\hline $\begin{array}{c}\text { - Crowding index: } \\
\leq 2 \\
>2\end{array}$ & $\begin{array}{r}18(75) \\
6(25)\end{array}$ & $\begin{array}{r}11(91.7) \\
1(8.3)\end{array}$ & $0.23 *$ & $\begin{array}{l}58(62.4) \\
35(37.6)\end{array}$ & $\begin{array}{l}9(64.3) \\
5(35.7)\end{array}$ & $0.9 *$ \\
\hline 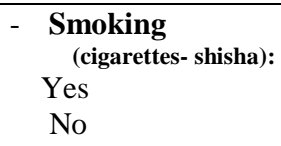 & $\begin{array}{r}3(7.5) \\
37(92.5)\end{array}$ & $\begin{array}{r}1(5.6) \\
17(94.4)\end{array}$ & $0.63 *$ & $\begin{array}{r}7(1.0) \\
711(99.0)\end{array}$ & $\begin{array}{r}3(2.7) \\
107(97.3)\end{array}$ & $0.14 *$ \\
\hline $\begin{array}{l}\text { - Addiction: } \\
\text { Yes } \\
\text { No }\end{array}$ & ---------- & ----------- & ---------- & $\begin{array}{r}2(0.3) \\
716(99.7)\end{array}$ & $\begin{array}{r}0(0) \\
110(100)\end{array}$ & $0.8^{*}$ \\
\hline
\end{tabular}

SD: standard deviation, IQR=interquartile range, ${ }^{*}$ Chi-square, $* *$ Mann Whitney test.

Numbers may count to less than the total because of missed responses, valid percents were used.

reported having psychiatric problems. But this disagrees with Kowal et al, who indicated in his study that many women suffer neurological, mental, and physical problems. ${ }^{13}$ Similarly in Crandall study, $18 \%$ of mothers were clinically depressed and $33 \%$ of them had suicidal ideas. ${ }^{14}$ Also, in the current study, the presence of more than 2 morbidities showed to be significantly higher among the group of females heading a family with an odds ratio of approximately three. Women heading a family are more prone to have more than 2 morbidities. This is close to that of a study performed in Iraq ${ }^{15}$ where diseases for which stress is known to be a risk factor like hypertension, diabetes, heart disease are prevalent in the studied WHF. Riyadh ${ }^{7}$ found that irritable bowel disease is of a relatively high rate at $2.7 \%$; its relation to anxiety and stress is well known. In the present study, there was significant difference in age in both groups regarding whether the females had 2 or less comorbidities or more than 2 comorbidities; with increasing comorbidities as the mean age increases. A significant difference was also found in the group of females not heading a family regarding their educational status showing less comorbidities with better status of education. This comes in concordance with Nejati study which mentioned that chronic health conditions increases with Age in female headed households. ${ }^{17}$

\section{Conclusion and}

\section{Recommendations:}

The health status of women headed house hold is not desirable. Therefore, the need for effective innovative intervention programs to improve health and enhance the quality of life for this group of women is one of the priorities of the society. Paying attention to these families and assisting them are of special duties of the government, private institutions, and other people. However, assisting these families must be beyond financial support. In this regard, empowering and training Femaleheaded households are the possible important actions. Employment, training 
professions, and offering low-interest loans and facilities, for example for weaving carpets, buying land and encouraging farming, and so forth, may make a strong secure conditions in the society for them.

Funding: This work was supported by the Department of Public Health and Community Medicine -Faculty of Medicine Cairo University- Research Consortium.

\section{Acknowledgement:}

We would like to thank Eman Osman for her help and contribution in data cleaning, data analysis and her support and assistance in scientific writing in some parts of this research. We extend our thanks also to the Public health and Community Medicine Department Faculty of Medicine Cairo University Research Consortium for their support in this work.

\section{References:}

1. UN Economic and Social Council (2017). Progress towards the Sustainable Development Goals: Report of the SecretaryGeneral (E/2017/66).

2. The importance of women Health (2018). [Online] Available from: http://www.keralawomen.gov.in/index.php/hea lth/190-the-importance-of-women-s-health.

[Accessed 19th January 2018].

3. Women's Health Neglected throughout history, Women's Health is now coming to the forefront (2018). [Online] Available from: http://www.healthylife-

healthyplanet.com/womenshealth.html.

[Accessed 13th January 2018].

4. Seyed HZ (2011). Empowerment of Female headed households, Case Study. Sedighin charity institution in Iran; ARTICLE: 6-12.

5. Baros R, Fox L (1997). Female headed households, poverty and welfare of children in urban Brazil. Economic Development and Cultural Change; 45 (2): 231-257.

6. Min Z, Michael S (2003). Assets, Expectations, and Children's Educational
Achievement in Female-Headed Households. The Social Service Review; 77 (2): 191-211.

7. Riyadh KL, Ali HH and Jamal MK (2012). Medical and social problems among women headed families in Baghdad. Qatar Med J; 2012 (2): 51-58.

8. PHCM (Public Health \& Community Medicine - Field \& Practical Guide) (2016). Module (1): health service, programs \& management, Chief Editor El lawindi M.I., Publisher Maha Mobark- Cairo Egypt ISBN978-977-90-4139-1- pages (30-34).

9. Shin H (2006). Working and living arrangement of single mother households and social support in Mexico City. Summer research report. Austin, TX: Center for Latin America social policy, University of Texas at Austin.

10.ICRC (International Committee of the Red Crescent), Gorilla's Guides (2008). Iraq: Women struggle to make end meet. [Online] Available

from: http://www.icrc.org/eng/assets/files/201

1/iraq-update-01-02-2011-icrc-eng.pdf.

[Accessed 1st February 2008]

11.Rimaz S, Dastoorpoor M, Vesali Azar Shorbeyani S, Saiepour N, Beigi Z and Nedjat, S (2014). The Survey of Quality of Life and its Related Factors in Female-headed Households Supported by Tehran Municipality, Ddistrict 9. Iranian Journal of Epidemiology; 10 (2): 4855.

12. Khadim MS (2006). Indicators (signals) of human poverty for families that have been led by women, (A field study in city of Baghdad) Thesis (PhD). Arts College (sociology), Baghdad University.

13. Kotwal N, Prabhakar B (2009). Problems Faced by Single Mothers .J Soc Sci; 21(3): 197-208.

14. Marie C, Lakshmi S and Carol S (2010). Depression and thoughts of death among disadvantaged mothers: Risk factors and impact on maternal and child health. Archives of suicide research. Official journal of the International Academy for Suicide Research; 14(3): 248-60.

15.CNCDS, (2006). Chronic NonCommunicable Diseases Risk Factors Survey 
In Iraq. A STEP wise Approach. MOH with cooperation of WHO, MOPDC-COSIT. 16. Graham H, Blackburn C (1998). The socioeconomic patterning of health and smoking behaviour among mothers with young children on income support. Sociol Heal Illn; 20 (2):215-40.

17.Nejati V, Ashayeri H (2008). Health related quality of life in the elderly in Kashan. Iran J psychiatry Clin Psychol.; 14 (1):56-61.

\section{Quick Points:}

- $\quad$ House headed by women have become more significant phenomenon worldwide in the last half of 20 th and 21 th century.

- $\quad$ The increasing number of women headed households in developing countries are a result of economic changes and social pressures, rather than as a product of cultural patterns.

- $\quad$ The fact that many women juggle both work and the care of the home increases their susceptibility to poor health if care is not taken.

- $\quad$ The studied types of morbidities appeared to be represented higher in the group of females heading a family than in the other group.

- $\quad$ There is a need for effective innovative intervention programs to improve health and enhance the quality of life for women heading families is one of the priorities of the society. 